\title{
Counting Results of Great Bustard (Otis tarda, Linnaeus, 1758) between 2013-2020 in Eskişehir, Kütahya, and Afyonkarahisar Provinces
}

\author{
Mehmet Mahir KARATAŞ*, Ünal ÖZELMAS, İsmühan POTOĞLU ERKARA
}

Eskişehir Osmangazi University, Faculty of Arts and Science, Department of Biology, Zoology Section, Eskişehir, Turkey ORCID ID: Mehmet Mahir KARATAŞ: https:/ / orcid.org/0000-0002-3545-1464; Ünal ÖZELMAS: https://orcid.org/0000-0003-3533-0256; İsmühan POTOĞLU ERKARA: https://orcid.org/0000-0001-5780-4999

\begin{tabular}{|c|c|c|}
\hline Received: 24.01.2021 & Published online: 15.04 .2021 & Issue published: 30.06 .20 \\
\hline $\begin{array}{l}\text { Abstract: The Gr } \\
\text { "Vulnerable" in tl } \\
\text { estimates, Turkey } \\
\text { individuals. This } \\
\text { provinces betwee } \\
\text { population of } 205 \\
\text { individuals. The s } \\
14 \% \text { of Turkey's p } \\
\text { implementation o } \\
\text { areas. Detailed et } \\
\text { population declin }\end{array}$ & $\begin{array}{l}\text { (Otis tarda, Linneaus 1758) is a bird species categorized a } \\
\text { the IUCN and listed in both CITES and the Bern Conventic } \\
\text { ion makes up only } 1-2 \% \text { of the global population, whic } \\
\text { study was carried out in } 7 \text { different locations in Eskişe } \\
13 \text { and January } 2020 \text {. In summary, the surveyed areas were r } \\
\text { ls, a total breeding population of } 100 \text { individuals, and a } \\
\text { eas represent an average of } 17-29 \% \text { of Turkey's population ir } \\
\text { n breeding period, and an average of } 6-10 \% \text { of Turkey's popu } \\
\text { measures is required to prevent the population decline of } \\
\text { tudies on the species are recommended as a means of creati } \\
\text { mote population growth to healthy levels. }\end{array}$ & $\begin{array}{l}\text { Concern" in Europe and } \\
\text { II. According to the latest } \\
\text { esented by } 44.000-57.000 \\
\text { yya, and Afyonkarahisar } \\
\text { having a total wintering } \\
\text { mering population of } 70 \\
\text { g period, an average of } 8- \\
\text { ummering period. Urgent } \\
\text { Bustard within the study } \\
\text { eeasures to not only stop }\end{array}$ \\
\hline
\end{tabular}

Keywords: Turkey, vulnerable, Aegean, Inner Anatolia.

\section{Eskişehir, Kütahya ve Afyonkarahisar İllerinde 2013-2020 Yılları Arası Büyük Toy Kuşu (Otis tarda, Linnaeus, 1758) Sayım Sonuçları}

\begin{abstract}
Öz: Büyük Toykuşu (Otis tarda, Linneaus 1758), IUCN tarafından Avrupa' da 'Asgari Endişe Verici' ve Dünya çapında 'Hassas' olarak sınıflandırılan ve hem CITES hem de Bern sözleşmesinde EK-II'de (Kesin Koruma Altındaki Fauna Türleri) listelenen bir kuş türüdür. Son tahminlere göre Türkiye populasyonu, 44.000-57.000 birey ile temsil edilen dünya populasyonunun sadece \%1-2'sini oluşturmaktadır. Bu populasyon çalışması, Mart 2013-Ocak 2020 tarihleri arasında, Eskişehir, Kütahya ve Afyonkarahisar illerinde 7 farklı lokasyonda gerçekleştirilmiştir. Özetle, incelenen alanların toplam 205 bireyden oluşan bir kışlama populasyonuna, toplam 100 bireyden oluşan bir üreme populasyonuna ve toplam 70 bireyden oluşan bir yazlama populasyona sahip olduğu kaydedildi. İncelenen alanlar kışlama döneminde Türkiye nüfusunun ortalama \%17-29'unu, üreme döneminde Türkiye nüfusunun ortalama \%8-14'ünü ve yazlama döneminde Türkiye nüfusunun ortalama \%6-10'unu temsil etmektedir. Çalışma alanlarında Büyük Toykuşu populasyonunun azalmasını önlemek için acil koruyucu önlemlerin uygulanması gerekmektedir. Sadece nüfus düşüşünü durdurmak için değil, aynı zamanda nüfus artışını sağlıklı seviyelere çıkarmak için yeni tedbirler oluşturmanın bir yolu olarak türler üzerinde detaylı etolojik çalışmalar önerilmektedir.
\end{abstract}

Anahtar kelimeler: Türkiye; hassas; Ege; İç Anadolu.

\section{Introduction}

The Great Bustard (Otis tarda) is categorized as "Least concern" in Europe and "Vulnerable" in the world by the IUCN (Birdlife International, 2017). The species is listed in CITES Appendix I-II and the Bern Convention Annex II (Gao et al., 2008; Birdlife International, 2017). The Palearctic distribution range of the Great Bustard has decreased due to various threats during the last two centuries (Alonso et al., 2003b; Karakaş \& Akarsu, 2009). Throughout the previous decades, many European populations of the Great Bustard have come close to extinction or have become seriously endangered, with the exception being the Iberian and Russian populations. The Iberian population is considered to be stable and the Russian population is increasing (Alonso et al., 2003a, 2003b; Karakaş \& Akarsu, 2009; Birdlife International, 2017).
According to the latest estimates, Turkey's population makes up only $1-2 \%$ of the global population, which is represented by 44.000 to 57.000 individuals (Alonso \& Palacin, 2010; Birdlife International, 2017). Various population size studies have been conducted on the Great Bustard in Turkey, with each study producing different results. The most up to date studies give the total population size as approximately 700-1200 individuals (Morales \& Martin, 2002; Kılıç \& Karakaş, 2005; Palacin \& Alonso, 2008; Karakaş \& Akarsu, 2009; Alonso \& Palacin, 2010; Birdlife International, 2017). The species has two discrete subpopulations in Turkey. One of them is located in Eastern and Southeastern Anatolia and the other in the central and inner parts of Central Anatolia (Karakaş \& Akarsu, 2009).

Recent Great Bustard population status studies have been conducted on a regional basis (Kılıç \& Karakaş, 2005; Özbağdatlı \& Tavares, 2006; Karakaş \& Akarsu, 2009; 
Karataş, 2012; Azizoğlu, 2013; Karataş \& Özelmas, 2013) and the breeding ecology of the Great Bustard in the Muş plain has been studied (Tanriverdi, 2015). The population status of the Altıntaş Wildlife Development Area and the area between Körhasan - Aktaş - Ortaköy - Başkurt villages have previously been determined (Yarar \& Magnin, 1997; Karataş \& Özelmas, 2013). The area between Körhasan - Aktaş - Ortaköy - Başkurt villages (a part of the Aliken Key Biodiversity Area) is located in Eskişehir, and the Altıntaş Wildlife Development Area (WDA) is located in Kütahya. They are important bustard breeding areas in the national bustard action plan, since 40-60 individuals breed in the Inner-Western Anatolia region of Turkey (Eken et al., 2006; Özelmas \& Karakaya, 2011). In addition, these two areas are a part of the 97 Key Bird Areas (Yarar \& Magnin, 1997). Anecdotal evidence for the existence of this species in the province of Afyonkarahisar was given by the local people but had not been scientifically verified.

The presence of Great Bustard populations is also predicted to occur in areas other than the two main study areas. Therefore, our study's main purpose is to determine the population status of the Great Bustard which is distributed in different locations in Eskişehir, Kütahya, and Afyonkarahisar provinces in Turkey. Field surveys were conducted investigating the latest status of the species in areas where they have been proven to exist (Altıntaş Wildlife Development Area and Körhasan Aktaş - Ortaköy - Başkurt). Also, the existence of the species was investigated in the areas which had unproven anecdotal evidence sourced from interviews conducted with the local residents (Başmakçı - Dazkırı - Evciler, Aydınlar - Yenice - Döğer, Kalkanlı - Kıravdan, Kaymazyayla - Zaferhamit - Yeniköy, Kaymaz - Bahçeçik - Gerenli). Lastly, we investigated the possible presence of the species in areas within the provinces of Eskişehir, Kütahya, and Afyonkarahisar.

\section{Material and Methods}

\subsection{Study Area}

The field survey was conducted in 7 different locations in Eskişehir, Kütahya, and Afyonkarahisar provinces. These areas are Körhasan - Aktaş - Ortaköy - Başkurt (Area 1), Kaymaz - Bahçecik - Gerenli (Area 2), Kaymazyayla Zaferhamit - Yeniköy (Area 3), Kalkanl1 - Kıravdan (Area 4), Altıntaş Wildlife Development Area (Area 5), Aydınlar - Yenice - Döğer (Area 6), and Başmakçı - Dazkırı - Evciler (Area 7).

Area 1 is located between Çifteler and Sivrihisar in Eskişehir province (Fig. 1). Area 2 is located in Sivrihisar, Eskişehir province (Fig. 2). Area 3 is located between Çifteler, Sivrihisar and Mahmudiye in Eskişehir province (Fig. 3). Area 4 is located in Odunpazarı, Eskişehir province (Fig. 4). Area 5 is located between Altıntaş and Aslanapa in Kütahya province (Fig. 5). Area 6 is located between Altıntaş and İhsaniye in Kütahya and Afyonkarahisar province (Fig. 6). Area 7 is located between Başmakçı, Dazkırı and Evciler in Afyonkarahisar province (Fig. 7). The coordinates of the areas are not given as the Great Bustard is a "Vulnerable" species and there is a lot of poaching pressure on the Great Bustard. Areas are respectively $16.210 ; 8.731 ; 13.438 ; 5.211 ; 15.040 ; 26.013$; 26.771 hectares, and the elevation of the areas varies respectively between 830-930; 880-1010; 850-960; 925-994; $1000-1414 ; 1030-1170 ; 850-1080$ meters. Not all the areas have a protection status, except for Area 5, which is classified as a Wildlife Development Area (Karataş \& Özelmas, 2013).

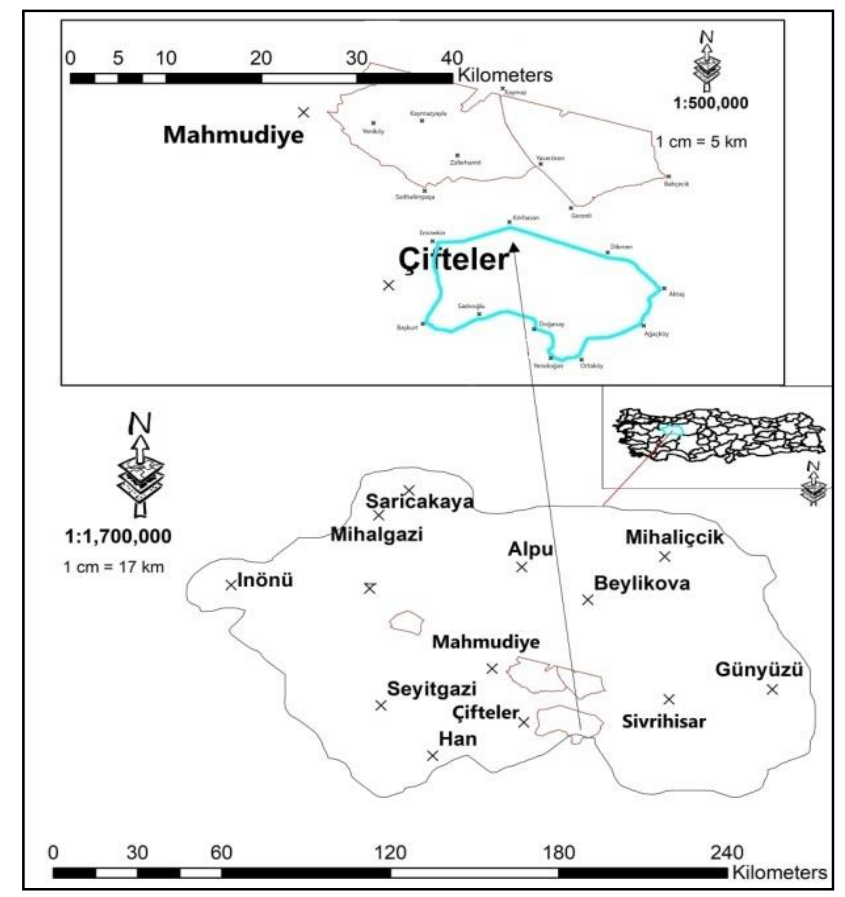

Figure 1. Map of Area 1.

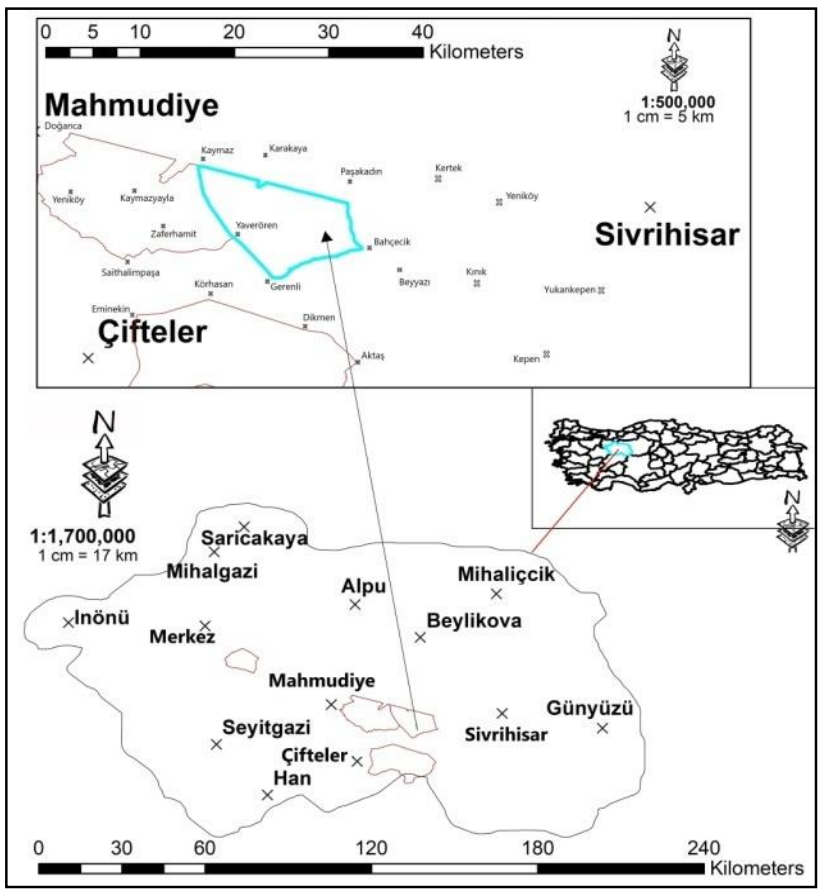

Figure 2. Map of Area 2.

In Area 1, there are cultivated areas, fallow lands, and uncultivated stony and marsh areas. Dry farming is carried out on the majority of the agricultural land in the area. However, irrigated farming practices have been increasing in recent years. In all areas, except Area 3, dry farming is carried out on the majority of the agricultural land and about half of the area is released fallow. However, irrigated farming is also performed partly. In Area 3, irrigated farming is carried out on most of the agricultural land in the area. However, dry farming is also performed partly. 


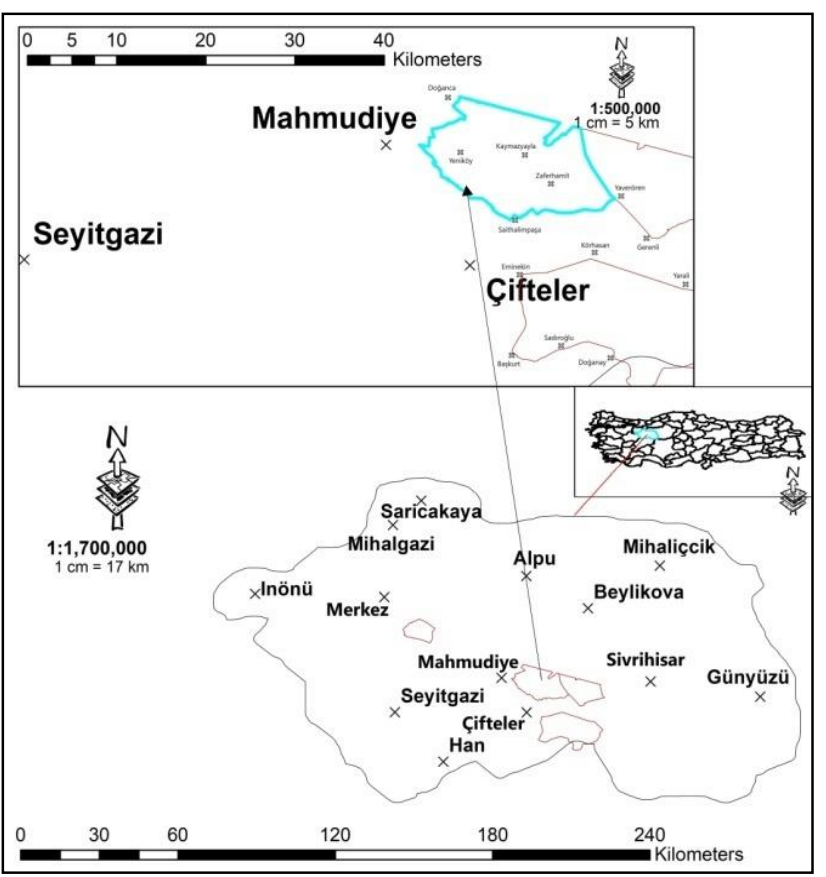

Figure 3. Map of Area 3.

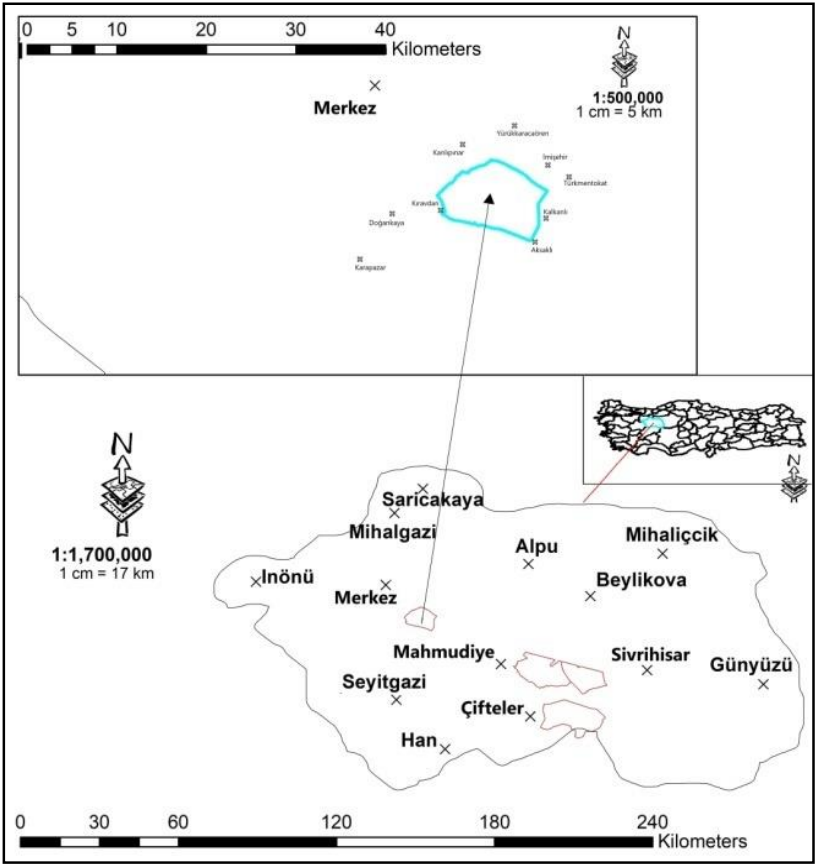

Figure 4. Map of Area 4.

\subsection{Method}

Field surveys were carried out for monitoring both the breeding and post breeding populations in the study area between March 2013 and January 2020, a total period of 7 years. Investigations were conducted using the transect and spot observation methods (Hellmich \& Idaghdour, 2002). Observation of the species was carried out in two periods, the first period beginning at dawn and lasting for 5 hours and the second period beginning 3 hours before sunset and finishing once the sun has set. These observation periods were selected because of the absence of obscuring weather phenomena (heat shimmer, etc.) and due to these periods being the most active times for the Great Bustard (Martinez, 2008). Date, hour, coordinate, number of individuals, sex, and age were recorded during the observations. Also, information was obtained about

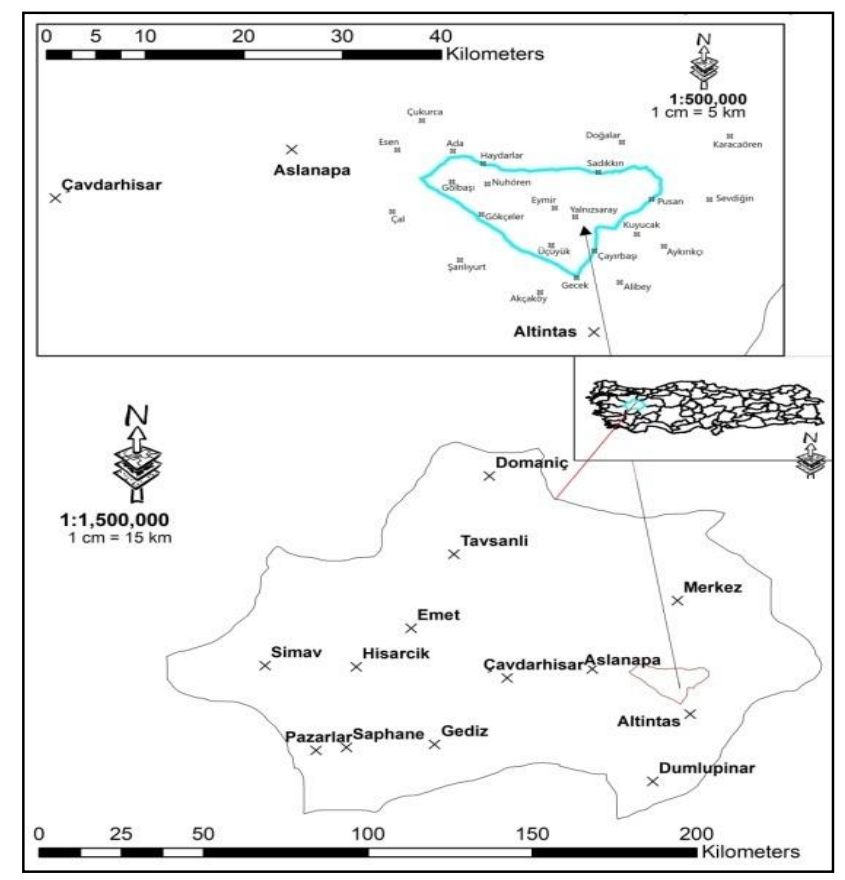

Figure 5. Map of Area 5.

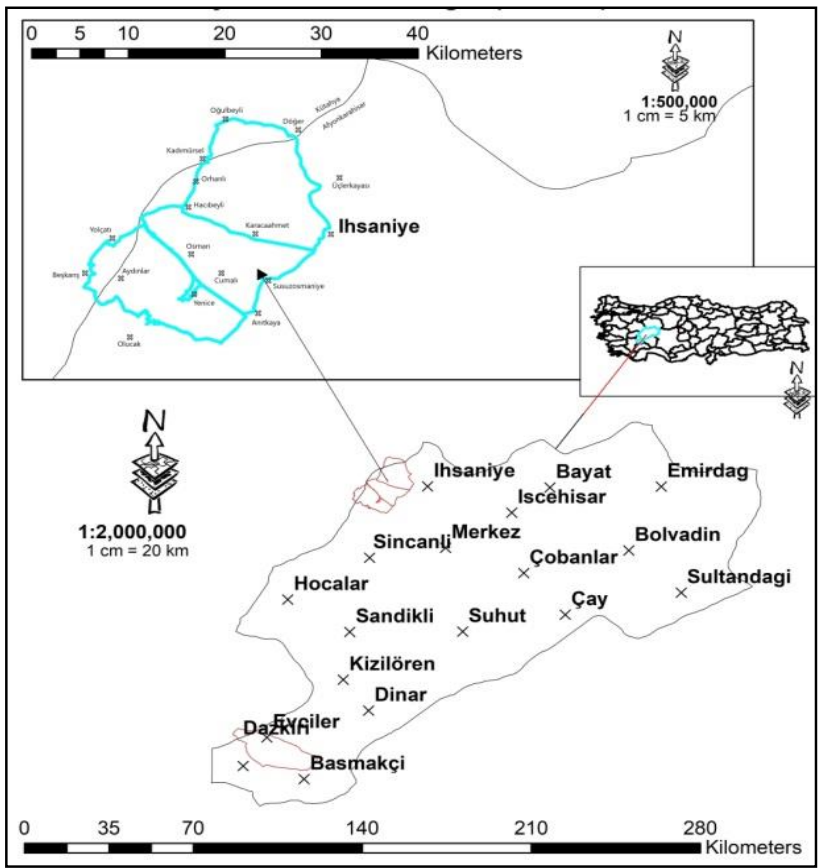

Figure 6. Map of Area 6.

the presence of the species in the area by interviewing the local people. To test the verifiability of the interviewees, a photograph of a Grey Heron (Ardea cinerea) was shown and was stated to be a Great Bustard (Hellmich \& Idaghdour, 2002). Data obtained by interviews were omitted from the count results. However, areas with strong anecdotal evidence were investigated more thoroughly.

Finally, count results were categorized under two subheadings, "Breeding season" which was classified as being between March-July and "Post-Breeding season" which was classified as being between August-February. The Post-Breeding season was separated between AugustNovember "Summering period" and between DecemberFebruary "Wintering period". 


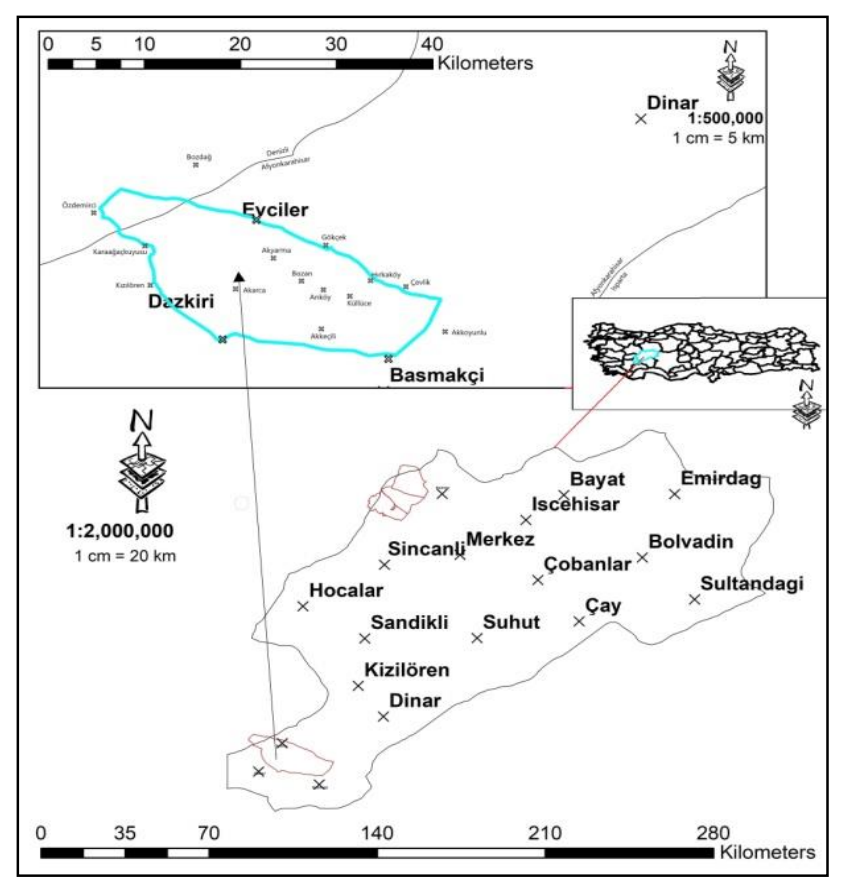

Figure 7. Map of Area 7.

\section{Results}

As a result of the field surveys, 1 locality was determined to be Lek Area in Eskişehir and 3 localities were determined to be Lek Areas in Afyonkarahisar where male individuals were observed exhibiting mating behaviors with a breeding plumage. 2 nests with 2 eggs were detected in Afyonkarahisar in May 2019 and 1 nest with 2 eggs in May 2019 and 1 nest with 3 eggs in May 2020 were recorded in Eskişehir.

As a result of the field observations carried out in Area 1 between March 2013 and January 2020, the greatest number of the recorded individuals in the breeding periods was 72 , on 11.04 .2015 . The greatest number of the recorded individuals in the summering periods was 36 , on 26.11.2018. The greatest number of the recorded individuals in the wintering periods was 33, both being recorded on 20.02.2019 and 26.01.2020.

In the breeding periods, it was determined that the female/male composition in the flock has changed over the years. This change is summarized in Figure 8.

This species is present all year around in Area 1 and utilizes the area for breeding, summering, and wintering (Fig. 9). As a result, this area hosts about 50-55 males and 11-17 females during the breeding period, around 25-35 individuals during the wintering period, and around 1015 individuals during the summering period.

In Area 2, between July 2017 and January 2020, the greatest number of the recorded individuals in the breeding periods was 26, on 02.03.2019. However, 1 nest with 2 eggs in May 2019 and 1 nest with 3 eggs in May 2020 were recorded in the study area. The greatest number of the recorded individuals in the summering periods was 80 , on 26.11.2018. The greatest number of the recorded individuals in the wintering periods was 130, on 26.01.2020. This species generally prefers this area as a summering and wintering location between SeptemberFebruary (Fig. 10). As an exceptional case, this species used this area as a nesting area in May 2019 and May 2020. As a result, this area hosts about 90-100 individuals during the wintering period and about 15-20 individuals during the summering period.

In Area 3, between April 2017 and February 2020, the greatest number of the recorded individuals in the breeding periods was 19, on 15.04.2017. The greatest number of the recorded individuals in the summering periods was 17, on 29.10.2018. The greatest number of the recorded individuals in the wintering periods was 30 , on 03.02.2020. This species generally prefers this area as a breeding and summering area, except for exceptional wintering cases (Fig. 11). As a result, this area hosts about 10-19 males and 2-3 females during the breeding period, about 15-20 individuals during wintering period, and about 11-17 individuals during the summering period.

In Area 4, between July 2018 and October 2019; the greatest number of the recorded individuals in the breeding periods was only 1, on 04.05.2019. Also, in April 2017, a nest with 2 eggs was spotted and photographed by the villagers. The greatest number of the recorded individuals in the summering periods was 7, on 28.10.2018. No individuals in the wintering periods were observed. This species generally prefers this area as a summering area between September-November and a nesting area between April-May (Fig. 12).

In Area 5, between March 2016 and October 2019, no individuals were encountered by our research teams at the study site. However, according to the inventory count studies carried out between March 2016 and October 2019 by The Nature Conservation and National Parks Kütahya Branch Directorate, the greatest number of the recorded individuals in the breeding periods was 43, in May 2016. The greatest number of the recorded individuals in the summering periods was 18, in September 2016. No individuals in the wintering periods were observed (Fig. 13).

In Area 6, between March 2016 and November 2019, the greatest number of the recorded individuals in the breeding periods was 4 males, on 06.03.2016. The greatest number of the recorded individuals in the summering periods was 10, on 31.10.2018 and 25.11.2018. The greatest number of the recorded individuals in the wintering periods was 3, on 05.12.2018. This species generally prefers this area as a summering area, except for exceptional cases during breeding and wintering (Fig. 14).

In Area 7, between July 2016 and January 2020, the greatest number of the recorded individuals in the breeding period was 40, on 15.03.2019. In addition to this, 3 different areas were identified as the Lek area of this species in April 2019 and the female/male composition of this flock is 11 females/13 males. 2 nests with 2 eggs were detected in May 2019. The greatest number of the recorded individuals in the summering periods was 30, on 24.11.2018. The greatest number of the recorded individuals in the wintering periods was 105, on 20.12.2019. This species is present all year round in Area 7 and utilizes the area for breeding, summering, and wintering (Fig. 15). As a result, this area hosts about 16-26 males and 7-11 females during the breeding period, about 60-70 individuals during wintering period, and about 1020 individuals during the summering period. 


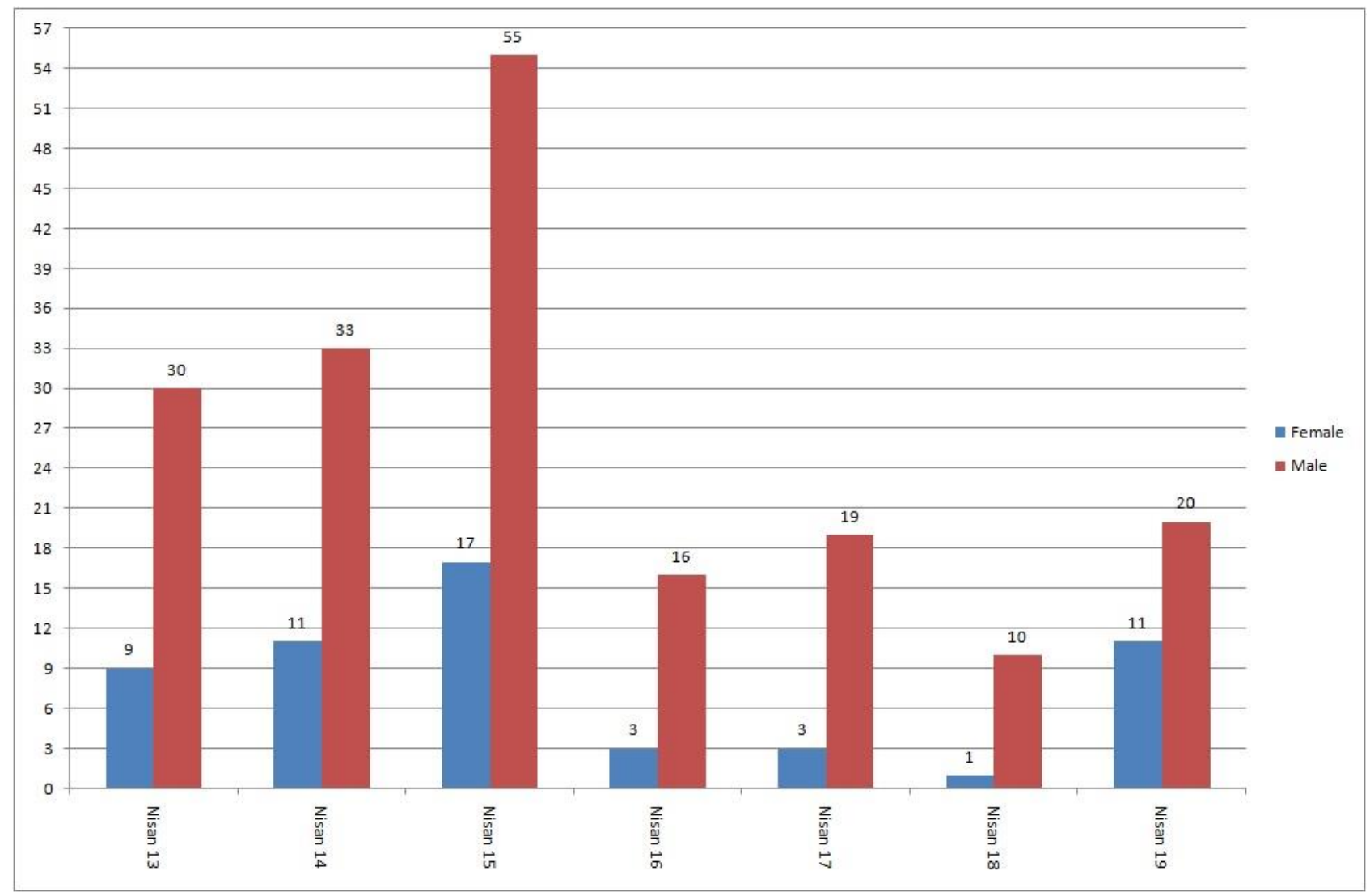

Figure 8 . The change over the years of female/male composition in the flock.

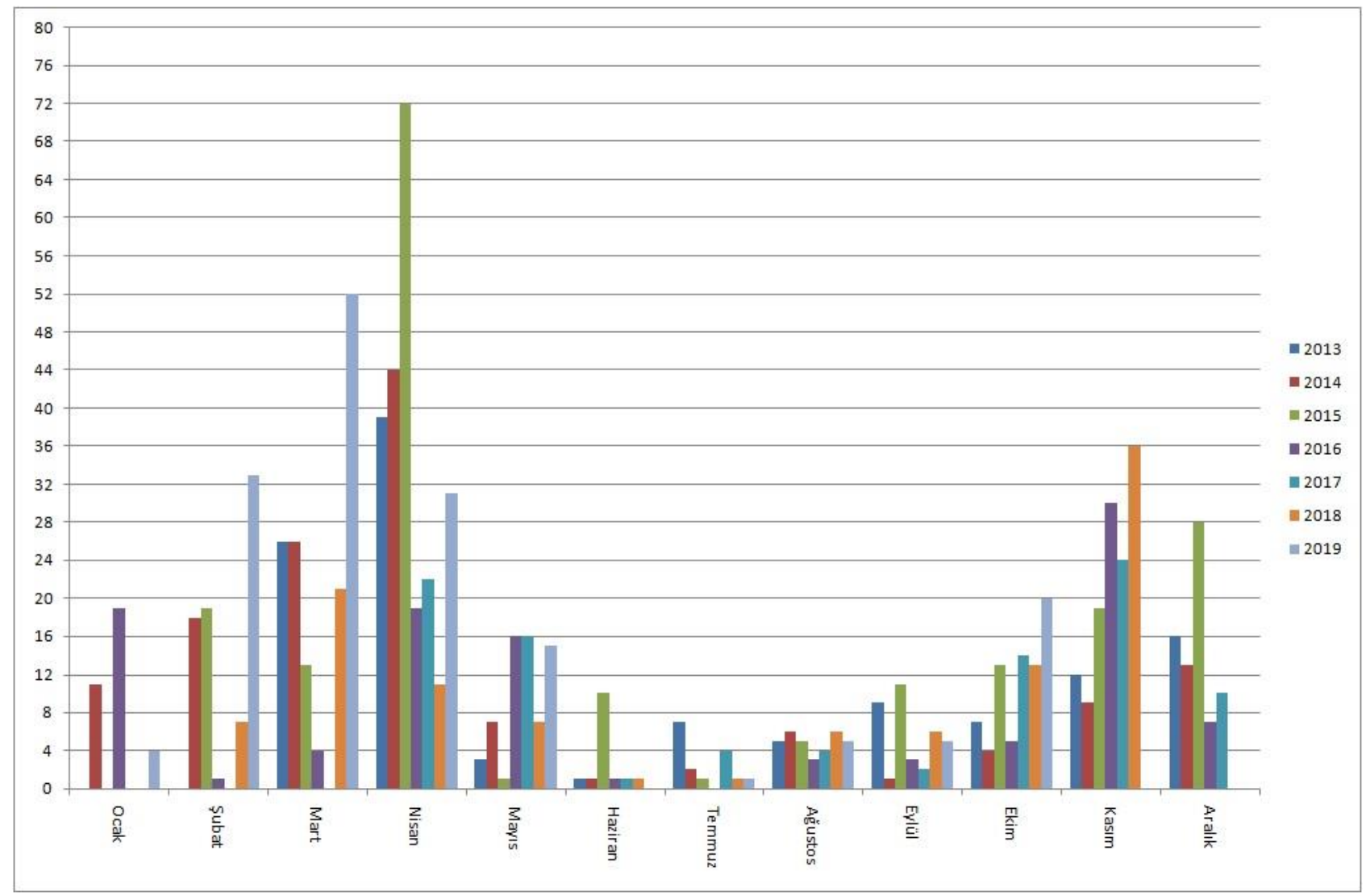

Figure 9. Annual and monthly changes in the number of individuals in Area 1. 


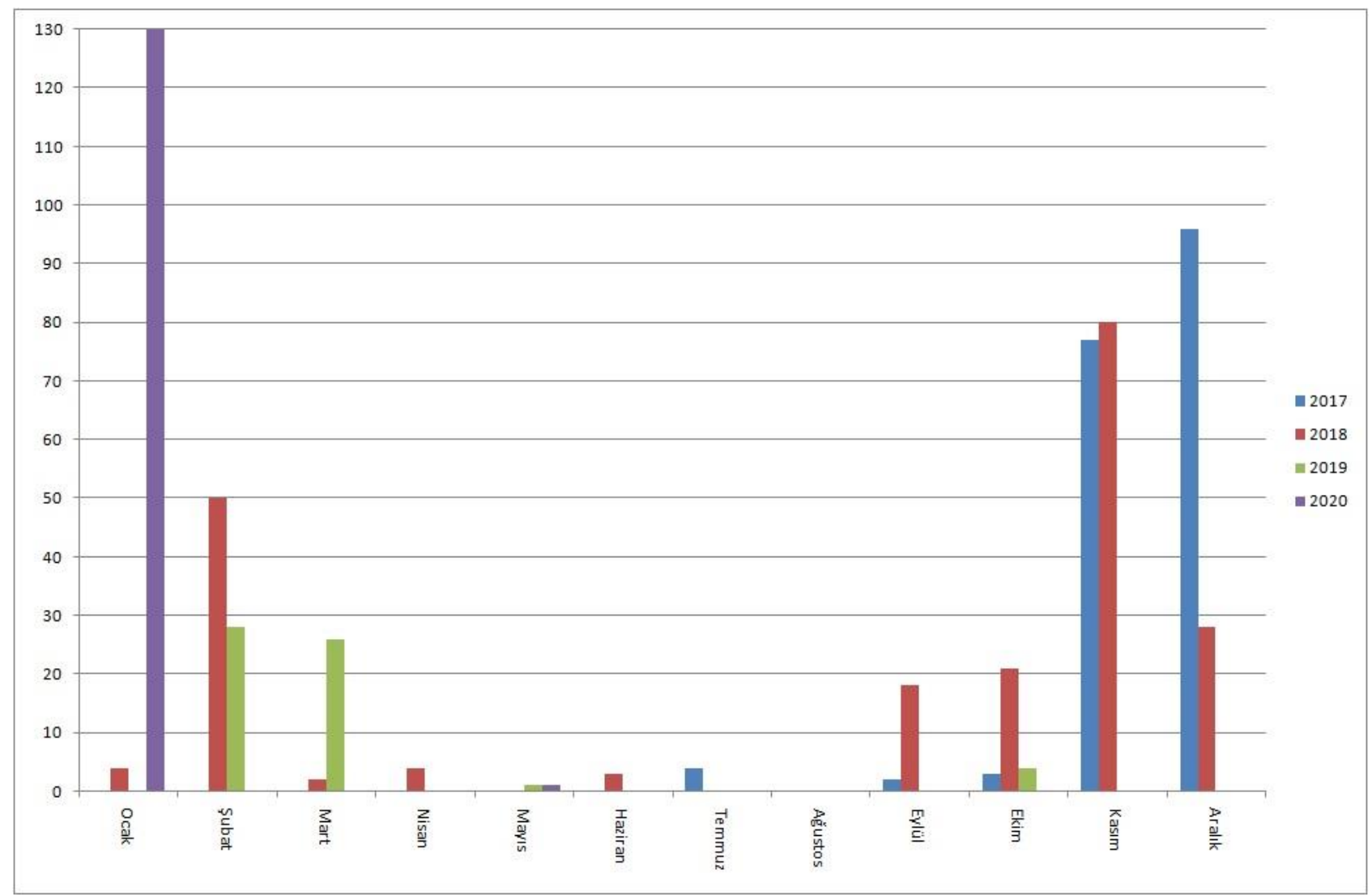

Figure 10. Annual and monthly changes in the number of individuals in Area 2.

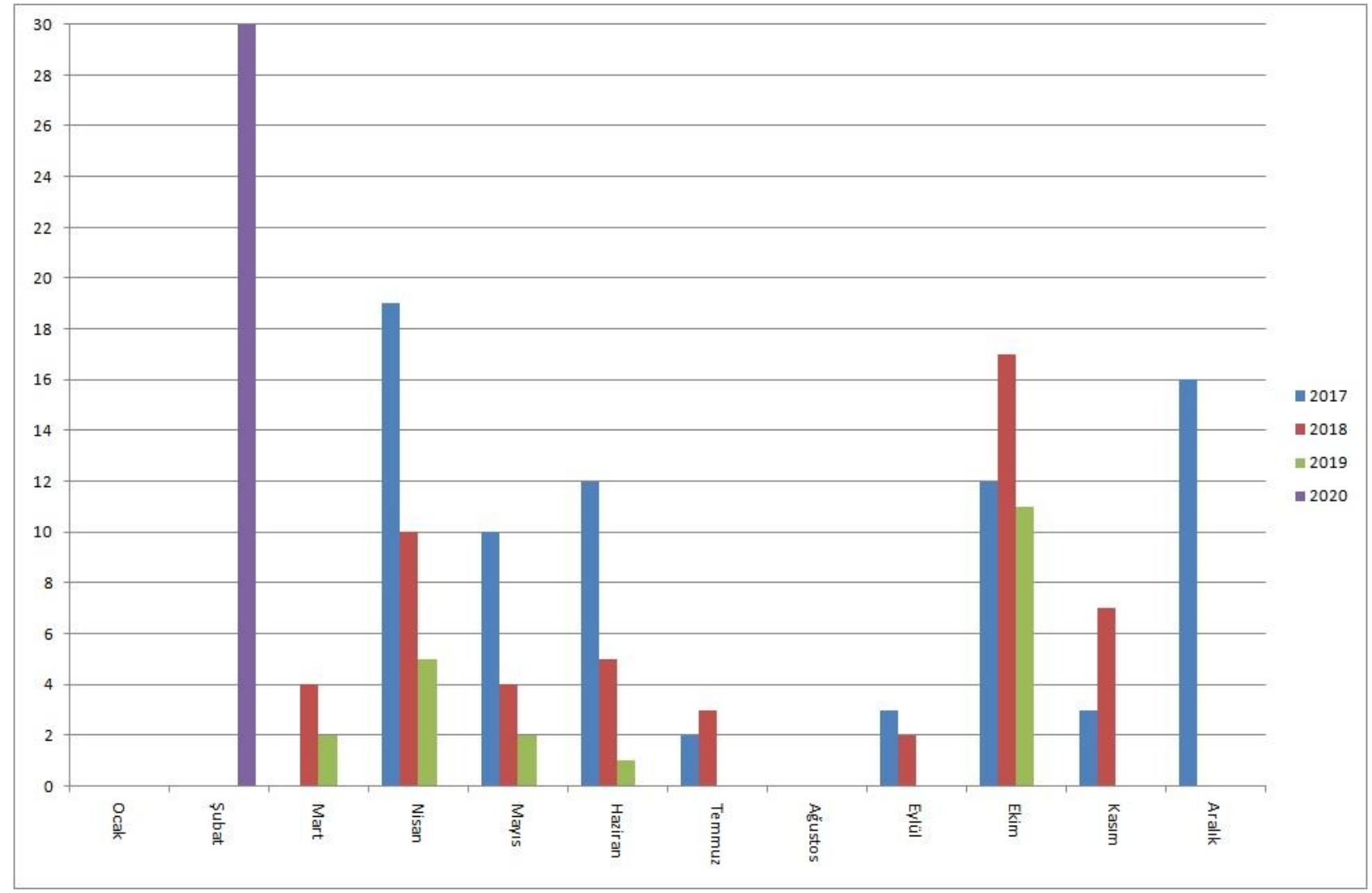

Figure 11. Annual and monthly changes in the number of individuals in Area 3. 


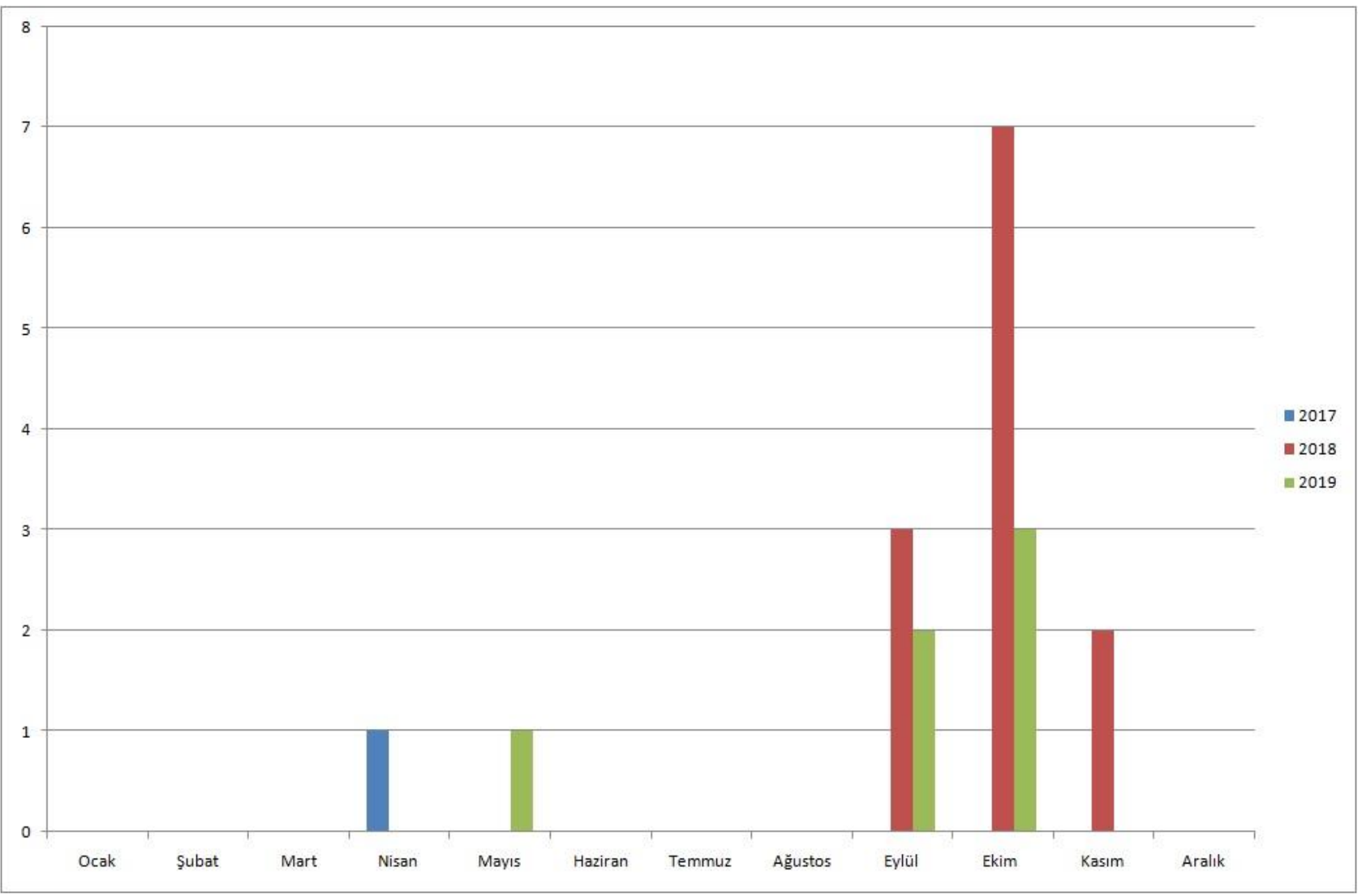

Figure 12. Annual and monthly changes in the number of individuals in Area 4.

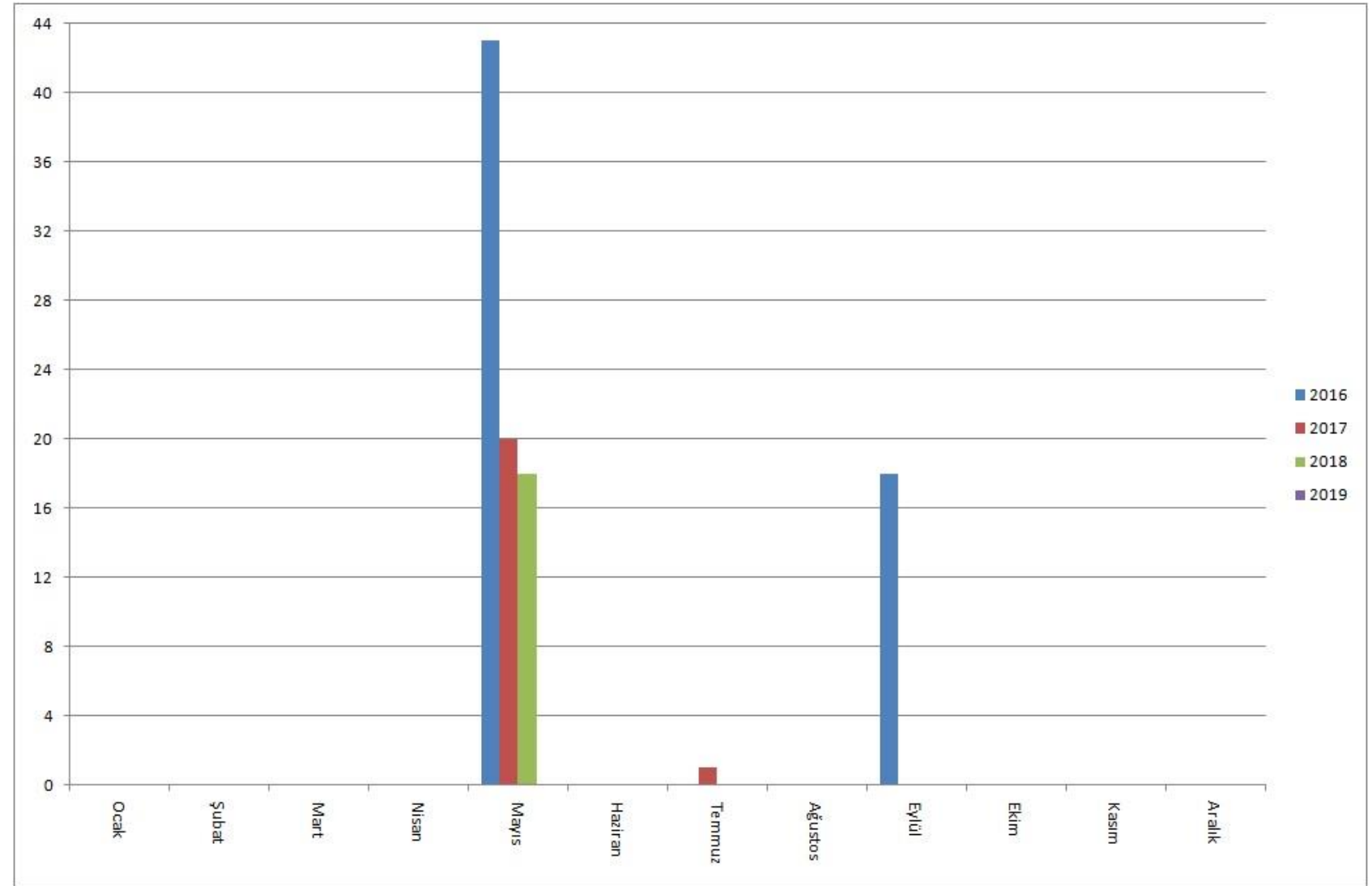

Figure 13. Annual and monthly changes in the number of individuals in Area 5. 


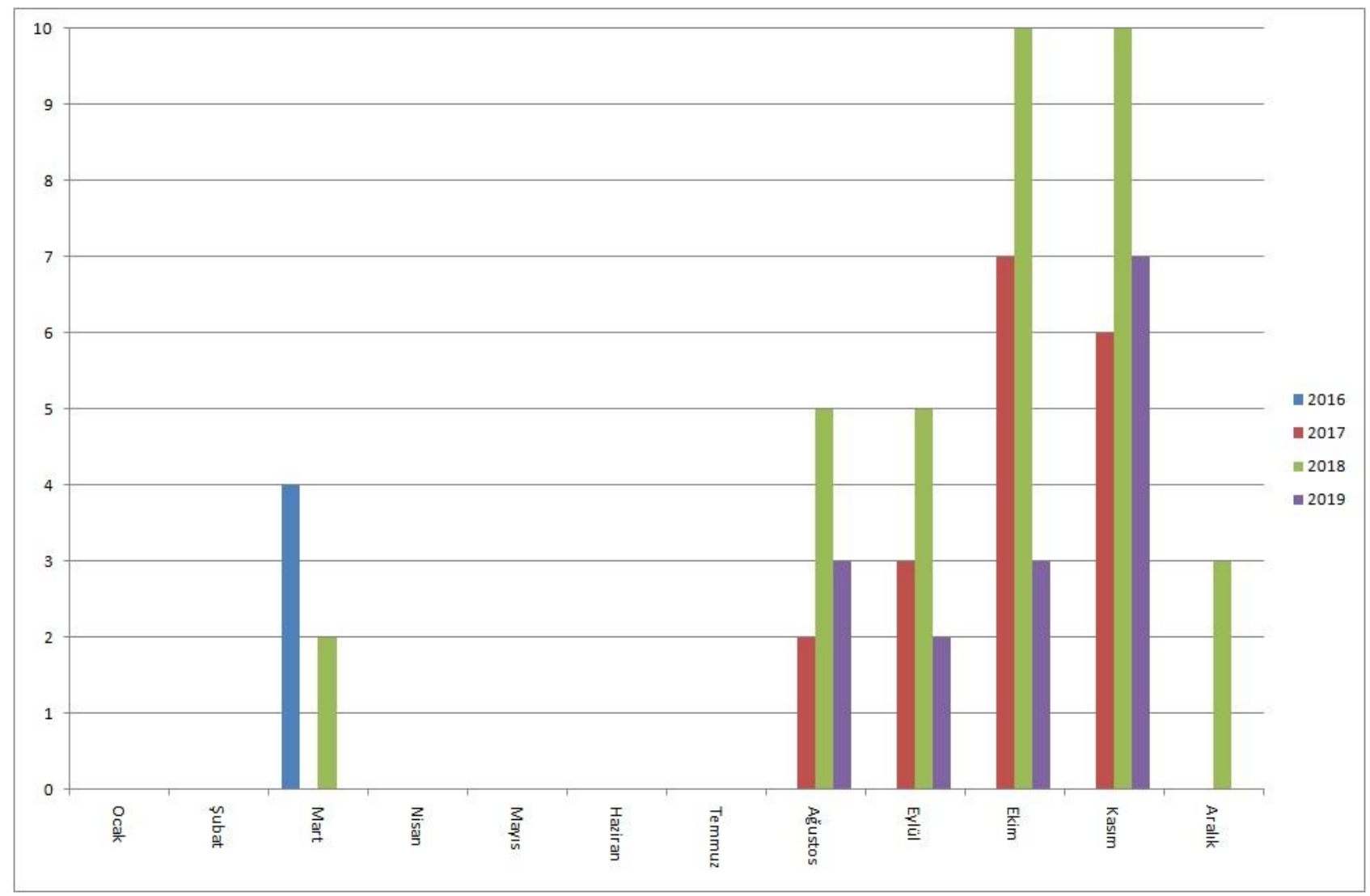

Figure 14. Annual and monthly changes in the number of individuals in Area 6.

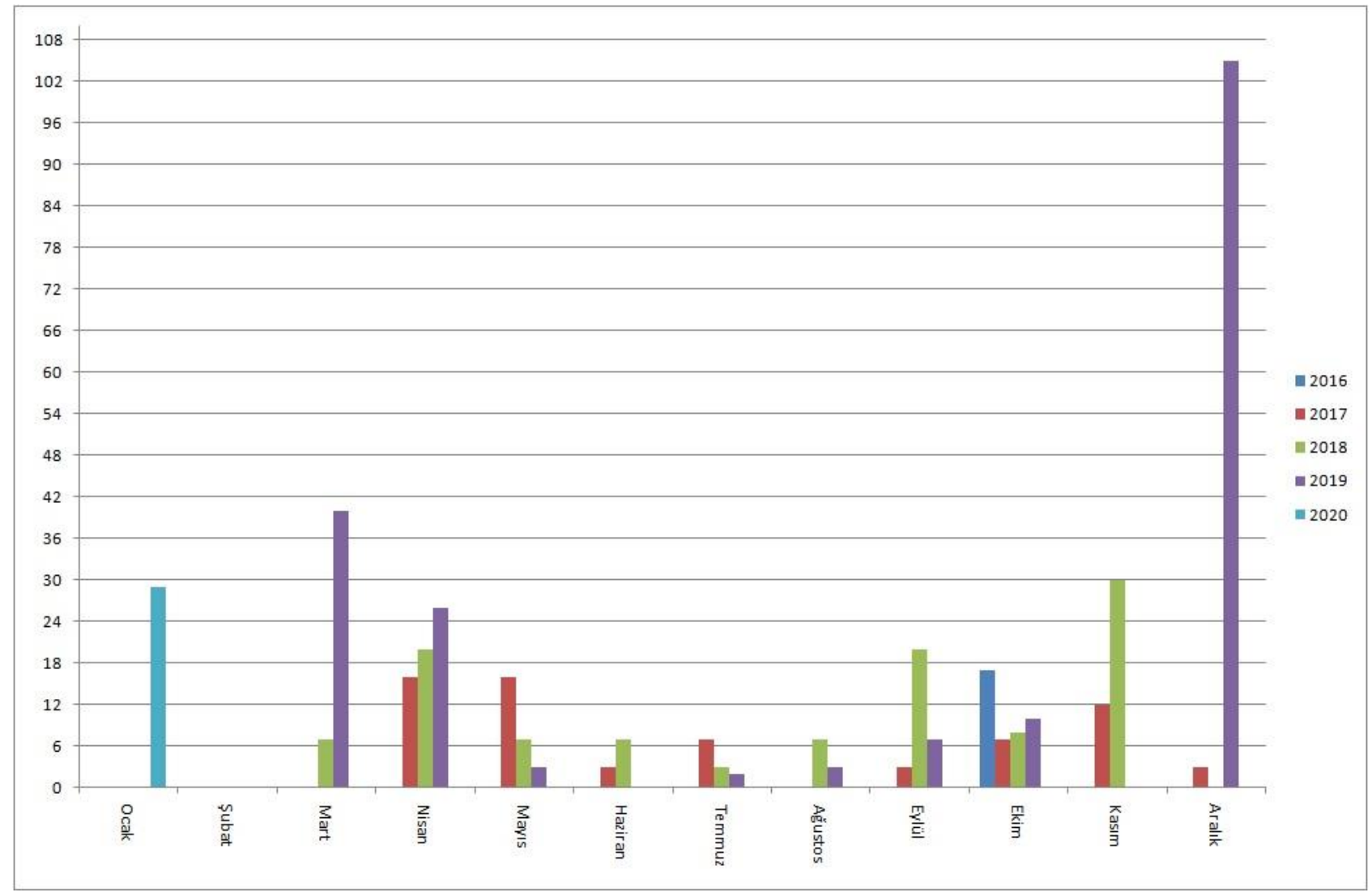

Figure 15. Annual and monthly changes in the number of individuals in Area 7.

Finally, it has been determined by the team involved in this study that individuals belonging to this species are encountered irregularly during some periods of the year in Ablak - Ümraniye - Camili - Aydınyaka and Yenikapı - Kılıçlar villages of Emirdağ district of Afyonkarahisar province and the villages of Benlikuyu - Eskiakören, 
Paşakadın, and İlyaspaşa in Sivrihisar District of Eskişehir province. Also, due to the fact that this species could not be caught and marked in some way to distinguish from each other, the population number that we declare as the study results is the maximum number of individuals observed at one time.

\section{Discussion}

The number of Great Bustards Turkey accounts for only 1$2 \%$ of the Great Bustard world population and consists of approximately 700-1200 individuals (Morales \& Martin, 2002; Kılıç \& Karakaş, 2005; Palacin \& Alonso, 2008; Karakaş \& Akarsu, 2009; Alonso \& Palacin, 2010; Birdlife International, 2017). In summary, 7 surveyed areas were recorded as having a total breeding population of 100 individuals, a total summering population of 70 individuals, and a total wintering population of 205 individuals. The surveyed areas represent an average of 8$14 \%$ of Turkey's population in breeding period, an average of $6-10 \%$ of Turkey's population in summering period, and an average of $17-29 \%$ of Turkey's population in wintering period.

Area 1 holds about 50-55 males and 11-17 females during the breeding period, about 25-35 individuals during the wintering period, and about 10-15 individuals during the summering period. Area 7 holds about 16-26 males and 7-11 females during the breeding period, about 60-70 individuals during the wintering period, and about 10-20 individuals during the summering period. Area 3 holds about 10-19 males and 2-3 females during the breeding period, about 15-20 individuals during the wintering period, and about 11-17 individuals during the summering period. Area 2 holds about 90-100 individuals during the wintering period and about 15-20 individuals during the summering period. These areas are the most important areas among seven study areas where this species has spread and these areas should absolutely be protected.

When the study areas are compared with each other in terms of the number of individuals they host, Area 1 during the breeding period, Area 2 during wintering period, and the Area 2 during the summering period are the most important ones. However, Area 7 is as important as Area 1 and Area 2 in all three periods: breeding, wintering, and summering due to its location. There are fewer settlements around the Area 2 study area and there is no sheep farming. Therefore, they encounter fewer uneasiness factors during the winter and summer periods when compared to other areas. The main reason for the increased number of individuals during the breeding period of the Area 1 study area is that this species is loyal to the lek areas and comes to the same spot during the breeding period every year. The reason for the difference in the number of individuals between the same months in different years is that our species moves to alternative areas inside or outside the area when nutrients are lacking. The increased unrest of the species is due to the agricultural activities in the area and unsuitable climatic conditions such as heavy snow cover. Also, since the species perceive incoming danger from distances as far away as $1 \mathrm{~km}$ and flies away or hides itself, it cannot be observed and is therefore not included in the census results. These factors may account for the difference in the number of individuals.
Karataş (2012) reported the population figure recorded in the Altıntaş Wildlife Development Area during the study period between 2010 and2012 as 8 individuals, consisting of 5 females and 3 males. This species may become extinct within the Altıntaş Wildlife Development Area within the next 10 years if protection measures against the factors threatening the species within the study area are not implemented immediately. Mainly during the breeding period, only 1 male and 1 female individual were observed in individual field studies conducted between 2015-2019 in and around the location where individuals are regularly seen. This situation suggests that this species' population within the Altıntaş Wildlife Development Area may become extinct. Continuing to carry out more detailed field studies including the areas outside the current study area is imperative and necessary for the future of this sensitive species in Altıntaş WDA.

Populations globally and in Europe are defined as completely immigrant (Birdlife International, 2017). However, among the populations; highly variable migration behaviors are exhibited including forced winter migrants (Asian and Russian populations), partial summer migrants and winter visitors with a gender differential model, and facultative migrants (central European population) (Morales et al., 2000; Alonso et al., 2000, 2001; Palacin et al., 2009, 2011; Birdlife International, 2017). Most western subspecies are partially immigrants but eastern subspecies in eastern Russia, northeast China, and Mongolia are completely immigrants (Kessler et al., 2013; Birdlife International, 2017). This species is tolerant of cold, but in some cases, regular or irregular displacements can be seen in indigenous populations during severe and heavy winters (Morales \& Martin, 2002). In addition, sometimes successful wintering in advantageous areas may cause these areas to become a traditional winter area in the next period (Morales \& Martin, 2002). Many populations are indigenous to Turkey but some populations perform seasonal movements within the country. For example, eastern populations descend southward in the winter period November-December in Turkey during which they are regularly found near Şanlıurfa (Tanriverdi, 2015). The Great bustard was defined as "local" as they were observed throughout the year in Area 1 and Area 7. However, in Area 2, it is thought that this area is a "wintering area" that is visited regularly due to the increasing population, especially in NovemberJanuary compared to other months. In addition, in this area which is defined as a wintering area, it is necessary to investigate in a more detailed study using marking and satellite tracking systems to determine where the wintering individuals come from.

The Female/male ratio was $1.10 / 1$ and $1.41 / 1$ in Spain's Entradas and Marcos regions (Morgado \& Moreira, 2000 ), the female/male ratio was 2.42/1 in Madrid (Alonso et al., 2003a), it was 1.6/1 in Villafáfila (Alonso et al., 2003b), 2.99/1 in 2003, 3.12/1 in 2004 in Osuna (Alonso et al., 2005a). The female/male ratio was $2.4 / 1$ in 2007 in Madrid (Martín et al., 2007), it was 3.29/1 in 2002, 5.67/1 in 2005, (Alonso et al., 2005b) and 3.80/1 in 2016 in Morocco (Palacin et al., 2016), The 3-year average female/male ratio is $2.57 / 1$ in China's Tacheng and Qapqal regions (Wang et al., 2018). In addition, the female/male ratio was determined as $1.6 / 1$ during the 
breeding periods of 2010-2012 in Altıntaş WDA (Karataş, 2012). On the other hand, the female/male ratio was determined as $1 / 3.3$ in $2013 ; 1 / 3.0$ in $2014 ; 1 / 3.2$ in 2015; 1/5.3 in 2016; 1/6.3 in 2017; 1/10 in 2018 and 1/1.8 in 2019 in Area 1 . Also, the female/male ratio was determined as $1 / 1.2$ in 2019 in Area 7. The fact is that while more females were observed than males in a global scale, in Area 1 more males were observed than females. This may be due to the fact that no matter how detailed we make our field studies, we cannot observe very well camouflaged female individuals, which means that their population situation may be approximately 1.5 times more than our estimates. This shortfall in our estimates may be caused by a special situation specific to our work areas. In both possibilities, this situation should be investigated in detail with branding and satellite tracking systems.

Magana et al. (2010) found out that most of Spain's nesting areas were in the cultivation and fallow areas, there were only a few nests in the ploughed areas. Tanriverdi (2015) found out that in the Muş Plain, all of the nesting areas were in the cultivation areas. In this study, although almost all of the nests are in the cultivation areas, the nest in the Area 7 in 2019 was found in the Garden rocket (Eruca vesicaria) fields. Although it has been reported in the literature that this plant species was included among the feeding preferences in Portugal's spring season (Morales \& Martin, 2002), no nest registration was reported for this plant species. However, records show that a nest was built in a weedy or meadow area. Rather than the type of plant in the area where the nest is built, it is thought that the nest must be built in a uniform and non-segmented pattern to protect the nest against dangers. Of course, this prediction needs to be investigated in detail with satellite tracking systems.

Although the Great Bustard prefers different areas in different seasons as their habitat preferences, they generally avoid small clustered or isolated park areas of forests and trees. On the other hand, it is known that they use open oak forests and olive groves in the Iberian Peninsula. In Turkey, only in Kars, 1 female and 3 cubs were observed on the edge of pine forests (Pinus sylvestris) in 2011 (Per et al., 2012). In our field studies, it is determined that uninterrupted mobility in all directions on the ground and having a clear field of view over $1 \mathrm{~km}$ is absolutely necessary for the Great Bustard to choose an area. Although individuals of this species prefer treeless areas with at least $1 \mathrm{~km}$ uninterrupted visibility in Eskişehir province every season, individuals who live in Area 6 and Area 7 prefer Hawthorn (Crataegus pseudoheterophylla) areas to rest in the summer months unlike the individuals in Eskissehir. It is thought that the birds choose the areas which contain these plants to protect themselves from extreme temperatures in summer months.

The threat factors are reported for the Great Bustard are: human presence and disturbance during agricultural activities especially during the breeding season, pesticide usage, habitat loss due to infrastructural changes such as the construction of village roads and electric transmission lines, leakage hunting, collisions with electric transmission lines, and expansion of irrigation systems used in agriculture (Hellmich \& Idaghdour, 2002; Alonso et al., 2005b; Pinto et al., 2005; Sastre et al., 2009; Abdulkarimi et al., 2010; Lemus et al., 2011; Bravo et al., 2012; Horreo et al., 2013; Karataş et al., 2015; Karakaya et al., 2017). The threats mentioned by these authors have been observed in all our fields of study and they affect this species with a high degree of importance. Electricity transmission lines are especially a threat that needs to be solved first. Studies on electrical transmission line collisions in Spain, Portugal, Hungary, and Norway have shown that birds such as the Great Bustard, which are described as "weak fliers" which have particularly short wings and tails and high body mass, the risk of collisions with human-made structures such as electric transmission lines or wind turbines are extremely high and these collisions often result in death (Alonso et al., 2003a; Martin et al., 2007; Raab et al., 2010, 2012; Bernardino et al., 2018). The most serious threat is electricity transmission lines in Eskişehir, Kütahya, and Afyonkarahisar provinces where this species is spread. Electricity transmission lines pass around the lek areas in all three provinces. During our working period, electricity transmission line collisions occurred in Eskişehir on different days in May 2019 resulting in the death of two male individuals older than 8 years old. Collisions with electric wires can cause direct death of the species as well as the lesions caused by the collision and the effect of electric current on the body of this species. In order to prevent or reduce individuals of this species from colliding with electrical transmission lines, electrical wires may be marked to allow them to be seen from a distance or electric wires can be covered with insulating material to protect the electricity from being transmitted to the bird's body in the event of a collision. By marking the power lines, birds can reduce the risk of collisions by directing their flight around marked power lines, thereby reducing losses. However, marked power lines seriously affect the flight direction of birds. This causes birds to spend more energy. For this reason, it is recommended that the cables be underground rather than marking the power lines. In this way, all adverse effects of power transmission lines on this species will be eliminated (Raab et al., 2010).

Due to the high mortality rates in adult individuals from hunting in Central and East Asia and habitat loss, degradation, and fragmentation caused by land-use changes in Russia, central Asia, Morocco, and eastern Europe, the population of this species may rapidly decrease over the next three generations. For these reasons, this species has been classified as Vulnerable worldwide. However, with the successful conclusion of studies on the protection of this species and its habitats in Europe, especially in Spain in recent years, it is thought that the population of this species is unlikely to decrease rapidly over the next three generations; therefore, it has been classified as the Least Concern on the European scale. Unlike Europe, in Turkey, the population status of this species is adversely affected by habitat fragmentation resulting from the transition from dry farming practices such as wheat and barley to irrigated agriculture practices such as the production of sugar beet and corn. It is also negatively affected by the habitat destruction caused by infrastructural changes such as drilling for these irrigated farming practices, electrical lines, and by direct individual deaths such as collisions with electricity transmission lines and hunting. In addition, given the insufficient protection measures taken against the aforementioned adverse factors, it is considered likely that this species' population 
will decline rapidly over the next generations.

Creating a research and monitoring plan, a habitat management plan, a species management plan, laws and regulations, and raising the awareness and education of local people are recommended as protection measures. With the creation of an effective research and monitoring plan; every year spring, summer and winter censuses should be carried out in detail and the population status of the species should be checked continuously. Age and sex composition, population size, and the trends of populations should be observed. Habitat use, distribution patterns, movements, and factors causing death should be investigated. Considering all the areas where this species has spread to, the existence of key areas should be absolutely necessary for their vital activities such as breeding, resting and feeding, and whether key areas are needed should be investigated. Detailed ethological studies should allow an understanding of the species' preferences. With the creation of an effective habitat management plan; agricultural activities such as plowing, spraying, harvesting should be done while taking into consideration the life cycle of this species. Electricity transmission lines should be run underground to prevent collisions. The use of pesticides in or around the areas where the species lives should be restricted or prohibited with the support of various incentive methods. Within the areas where the species is found, "Key areas" should be created and protected with the help of incentives and rewards but preferably through raising awareness. Agricultural activities in these key areas should be restricted according to the breeding cycles of the species such as courtship, mating, and incubation. Agricultural practices that do not protect the habitats of this species, such as the degradation of fallow lands and the cultivation of crops for the second time should not be supported. Infrastructure and construction activities in or around the areas where the species lives should be restricted or completely banned. This involves taking into consideration the life cycle of the species. With the creation of an effective species management plan; local residents should be encouraged and rewarded if they report to the authorities when abandoned hatchlings or eggs or injured individuals are found. Rehabilitation and reproduction centers for the species should be established, and in these centers, wildlife-adapted individuals should be bred and released into the nature. The creation of an effective awareness raising campaign and a plan for the education of local people is required in order to protect the habitats of this species and to raise awareness about the conservation of this species. Meetings and interviews should be held among the people living in villages close to the Great Bustard habitats and training should be given to the students in schools within the local region. Finally, with the creation of effective laws and regulations; for the purpose of deterring and preventing the illegal hunting of the Great Bustard need to be implemented, instead of a rather insufficient and nondeterrent fine such as 8.679 Turkish Liras, a prison sentence should be imposed. In conclusion, we think that making the recommendations outlined in these plans will increase the success rates of regaining a healthy level of population.

Among the areas that have been identified in the National Bustard Action Plan, the current status of the Area 5 is Wildlife Development Area, and there are approximately 12 villages within the area with a total population of 5000 people. However, Area 1 ranks as one of the important bustard breeding areas, although there is not a recognized status for it. This population is the western part of Central Anatolia subpopulation. It is the biggest one in the Central Anatolia subpopulation with regard to breeding. For this reason, regardless of the area's protected status, protecting these 7 areas and supporting the Bustard studies in the area have great importance for the conservation of the Great Bustard on both a local and global scale. Also, detailed bio-ethological studies should be performed. According to the findings and results, new measures should be taken both in this local area and country-wide to enable the species to reach a healthy level of population.

Acknowledgements: This article has been produced from the $\mathrm{PhD}$ thesis titled "Behavior and Population Characteristics of Great Bustard (Otis tarda, Linnaeus 1758) Living in Eskişehir, Kütahya and Afyonkarahisar Province (644887)" conducted in the Department of Biology of Eskişehir Osmangazi University. Also, this article is the results of Scientific Research Project (BAP) coded 201319008 (2013-64) and 201619A232 (2016-1345) supported by Eskişehir Osmangazi University Scientific Research Project Commusion. Finally, we would like to thank employees of Republic of Turkey Ministry of Agriculture and Forestry Kütahya, Eskişehir and Afyonkarahisar Nature Conservation and National Parks for help.

Ethics committee approval: Ethics committee approval is not required for this study.

Conflict of interest: The authors declares that there is no conflict of interest.

\section{References}

Abdulkarimi, R., Daneshyar, M., \& Barati, A. (2010). Current status of the Great Bustard (Otis tarda) in Boukan, West Azerbaijan, Iran. Podoces, 5(1), 63-68.

Alonso, J.C., Morales, M.B., \& Alonso, J.A. (2000). Partial migration, and lek and nesting area fidelity in female Great Bustards. The Condor, 102, 127136.

Alonso, J.A., Martin, C.A., Alonso, J.C., Morales, M.B., \& Lane, S.J. (2001). Seasonal movements of male Great Bustards in Central Spain. Journal of Field Ornithology, 72(4), 504-508. https://doi.org/10.1648/0273-8570$\underline{72.4 .504}$

Alonso, J.C., Martin, C.A., Palacin, C., Magana, M., \& Martin, B. (2003a). Distribution, size and recent trends of the Great Bustard (Otis tarda) population in Madrid Region, Spain. Ardeola, 50(1), 21-29.

Alonso, J.C., Palacin, C., \& Martin, C.A. (2003b). Status and recent trends of the Great Bustard (Otis tarda) population in the İberian Peninsula. Biological Conservation, 110, 185-195.

Alonso, J.C., Martin, C.A., Palacin, C., Martin, B., \& Magana, M. (2005a) The Great Bustard (Otis tarda) in Andalusia, Southern Spain: status, distribution and trends. Ardeola, 52(1), 67-78.

Alonso, J.C., Palacin, C., Martin, C.A., Mouati, N., Arhzaf, Z.L., \& Azizi, D. (2005b). The Great Bustard (Otis tarda) in Morocco: a re-evaluation of its status based on recent survey results. Ardeola, 52(1), 79-90.

Alonso, J.C., \& Palacin, C. (2010). The world status and population trends of the Great Bustard (Otis tarda): 2010 update. Chinese Birds, 1(2), 141147.

Azizoğlu, E. (2013). Yüksekova (Hakkari) Nehil Sazlığı Ornitofaunası Üzerine Bir Araştırma (324444). Retrieved from https://tez.yok.gov.tr/UlusalTezMerkezi/giris.jsp

Bernardino, J., Bevanger, K., Barrientos, R., Dwyer, J.F., Marques, A.T., Martins, R.C.,......., \& Moreira, F. (2018). Bird collisions with power lines: State of the art and priority areas for Research. Biological Conservation, 222, 1-13.

BirdLife International, (2017). Otis tarda. The IUCN Red List of Threatened $\begin{array}{lll}\text { Species 2017: } & \text { e.T22691900A119044104. }\end{array}$ https://dx.doi.org/10.2305/IUCN.UK.20173.RLTS.T22691900A119044104.en 
Bravo, C., Ponce, C., Palacín, C., \& Alonso, J.C. (2012). Diet of young Great Bustards Otis tarda in Spain: sexual and seasonal differences. Bird Study, 59(2), 243-251. https://doi.org/10.1080/00063657.2012.662940

Eken, G., Bozdoğan, M., İsfendiyaroğlu, S., Kılıç, D.T., \& Lise, Y. (Eds.). (2006). Türkiye'nin Önemli Doğa Alanları [Key Biodiversity Areas of Turkey]. Doğa Derneği, Ankara, 34-35 ve 242-243, Turkey.

Gao, X., Yang, W., Qiao, J., Yao, J., \& Xu, K. (2008). Distribution and status of Bustards in China. Frontiers of Biology in China, 3(4), 385-391.

Hellmich, J., \& Idaghdour, Y. (2002). The Great Bustard (Otis tarda) population in Morocco 1998-2001. Bird Conservation International, 12, 1933.

Horreo, J.L., Palacin, C., Alonso, J.C., \& Mila, B. (2013). A link between historical population decline in the threatened great bustard and human expansion in Iberia: evidence from genetic and demographic data. Biological Journal of the Linnean Society, 110, 518-527.

Karakaş, R., \& Akarsu, F. (2009). Recent status and distribution of the Great Bustard (Otis tarda), in Turkey. Zoology in the Middle East, 48, 25-34.

Karakaya, M., Karataş, M.M., \& Özelmas, Ü. (2017). Agricultural pesticides used in Eskişehir and Kütahya population areas of Great Bustard (Otis tarda). Commagene Journal of Biology, 1(1), 25-30.

Karataş, M.M. (2012). Kütahya/Altıntaş Ovasındaki Büyük Toy Kuşu (Otis tarda, Linnaeus, 1758)'nın Populasyonu Üzerine Bir Çalışma (317867). Retrieved from https:/ / tez.yok.gov.tr/UlusalTezMerkezi/giris.jsp

Karataş, M.M., \& Özelmas, Ü. (2013). The study on the population of Great Bustard (Otis tarda) in Altıntaş plain, Kütahya/Turkey. Biological Diversity and Conservation, 6(3), 92-96.

Karataş, M.M., Karakaya, M., \& Özelmas, Ü. (2015). Agricultural pesticides used on Central West Anatolian (Eskişehir/Turkey) population areas of Great Bustard (Otis tarda). Biological Diversity and Conservation, 8(3), 254258

Kessler, A.E., Batbayar, N., Natsagdorj, T., Batsuur, D., \& Smith, A.T. (2013). Satellite telemetry reveals long-distance migration in the Asian great bustard Otis tarda dybowskii. Journal of Avian Biology, 44, 311-320.

Kılıç, A., \& Karakaş, R. (2005). Recent observation on the Great Bustard (Otis tarda), in South-eastern Anatolia. Zoology in the Middle East, 35, 99102

Lemus, J.A., Bravo, C., Garcia-Montijano, M., Palacin, C., Ponce, C. Magana, M., \& Alonso, J. C. (2011). Side effects of rodent control on nontarget species: rodenticides increase parasite and pathogen burden in Great Bustards. Science of The Total Environment, 409 (22), 4729-4734.

Martin, C.A., Alonso, J.C., Alonso, J.A., Palacin, C., Magana, M., \& Martin, B. (2007). Sex-biased Juvenile survival in a bird with extreme size dimorphism, the Great Bustard (Otis tarda). Journal of Avian Biology, 38, 335-346. https:// doi.org/10.1111/j.2007.0908-8857.03811.x

Magana, M., Alonso, J.C., Martin, C.A., Bautista, L.M., \& Martin, B. (2010). Nest-site selection by Great Bustards (Otis tarda) suggests a trade-off between concealment and visibility. İbis, 152, 77-89.

Martinez, C. (2008). Distribution, density and productivity of Great Bustards (Otis tarda) in Northwestern Spain: a regional approach. Journal of Ornithology, 149, 507-514.

Morales, M.B., Alonso, J.C., Alonso, J.A., \& Martin, E. (2000). Migration patterns in male Great Bustards (Otis tarda). The Auk, 117(2), 493-498.

Morales, M.B., \& Martin, C.A. (2002). Great Bustard (Otis tarda). BWP Update, 4(3), 1-16.

Morgado, R., \& Moreira, F. (2000). Seasonal population dynamics, nest site selection, sex-ratio and clutch size of the Great Bustard (Otis tarda) in two adjacent lekking areas. Ardeola, 47(2), 237-246.

Özbağdatlı, N., \& Tavares, J.P. (2006). The situation of Great and Little Bustard in Turkey, Bustard conservation in Europe in the Last 15 years; current trends, best practise and future priorities, RSBP/Birdlife, UK, p;33-38. Retrieved from https://www.dogadernegi.org/wpcontent/uploads/2015/09/Great-and-little-bustard-in-Turkey-toymakale.pdf

Özelmas, Ü., \& Karakaya, M. (2011). The ornithofauna of Eskişehir/Türkiye. Biological Diversity and Conservation, 4(2), 19-28.

Palacin, C., \& Alonso, J.C. (2008). An updated estimate of the world status and population trends of the Great Bustard (Otis tarda). Ardeola, 55(1), $13-25$.

Palacin, C., Alonso, J.C., Alonso, J.A., Martin, C.A., Magana, M., \& Martin, B. (2009). Differential migration by sex in the Great Bustard: possible consequences of an extreme sexual size dimorphism. Ethology, 115, 617626.

Palacin, C., Alonso, J.C., Alonso, J.A., Magana, M., \& Martin, C.A. (2011). Cultural transmission and flexibility of partial migration patterns in a long-lived bird, the great bustard Otis tarda. Journal of Avian Biology, 42, 301-308.

Palacin, C., Martín, B., Onrubia, A., \& Alonso, J.C. (2016). Assessing the extinction risk of the great bustard Otis tarda in Africa. Endangered Species Research, 30, 73-82. https://doi.org/10.3354/esr00726

Per, E., Özbek, M.U., Uzunhisarcıklı, M.E., \& Bilgili, B. (2012). Great Bustard Otis tarda in Turkey: adult female with three chicks at forest edge in Kars province. Sandgrouse, 34,148-150.

Pinto, M., Rocha, P., \& Moreira, F. (2005). Long-term trends in Great Bustard (Otis tarda) populations in Portugal suggest concentration in single high quality area. Biological Conservation, 124, 415-423.

Raab, R., Spakovszky, P., Julius, E., Schutz, C., \& Schulze, C.H. (2010). Effects of powerlines on flight behaviour of the West-Pannonian Great Bustard (Otis tarda) population. Bird Conservation International, 21(02), 142-155. https:// doi.org/10.1017/S0959270910000432

Raab, R., Schutz, C., Spakovszky, P., Julius, E., \& Schulze, C.H. (2012). Underground cabling and marking of power lines: conservation measures rapidly reduced mortality of West Pannonian Great Bustards Otis tarda. Bird Conservation International, 22, 299-306. https://doi.org/10.1017/S0959270911000463

Tanrıverdi, A. (2015). Mus ili sınırları içindeki Toy Kuşu (Otis tarda L 1758)'nun Üreme Ekolojisi Üzerine Araştırmalar (398781). Retrieved from https:/ / tez.yok.gov.tr/UlusalTezMerkezi/giris.jsp

Sastre, P., Ponce, C., Palacin, C., Martin, C.A., \& Alonso, J.C. (2009). Disturbances to Great Bustards (Otis tarda) in Central Spain: human activities, bird responses and management implications. European Journal of Wildife Research, 55, 425-432.

Wang, M., González, M.A., Yang, W., Neuhaus, P., Blanco-Fontao, B., Ruckstuhl, K.E. (2018). The Probable Strong Decline of the Great Bustard Otis tarda tarda Population in North-Western China. Ardeola, 65(2), 291-297.

Yarar, M., \& Magnin, G. (1997). Türkiye'nin Önemli Kus Alanları [Key Bird Areas of Turkey]. Doğal Hayatı Koruma Derneği. İstanbul, 114-120, Turkey. 